I Universidade Federal do Rio de Janeiro (UFRJ), Programa de PósGraduação em Antropologia Social (PPGAS), Rio de Janeiro, RJ, Brasil federico.neiburg@gmail.com https://orcid.org/0000-0002-9917-8604

\title{
ANTROPOLOGIA E ECONOMIA. TENTANDO FAZER UMA CONEXÃO SIGNIFICATIVA: ENTREVISTA COM KEITH HART
}

Keith Hart é um antropólogo que sempre desafiou os moldes da disciplina, tanto em seus formatos institucionais quanto em suas práticas de conhecimento. A entrevista que publicamos neste número de Sociologia \& Antropologia, realizada por nós na ocasião de sua participação no Colóquio Novas Perspectivas em Etnografia Econômica, no Museu Nacional, em 20I I, apresenta os múltiplos engajamentos, questionamentos e apostas de um antropólogo que encarna um momento da antropologia e do mundo, mas que o faz de forma extremamente singular, tanto por sua trajetória como por sua perspectiva e suas apostas intelectuais, que transcendem a antropologia enquanto disciplina acadêmica.

Conhecido como o autor que formulou o conceito de informalidade - e por esse motivo reconhecido fora dos círculos antropológicos -, Hart inicia-se na etnografia na década de I960 na recém-independente Gana. Orientado por Jack Goody, pertence a uma geração de antropólogos que observa e participa de um mundo em transformação, produto da descolonização e da consolidação

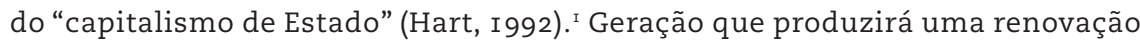
da antropologia britânica, não sem conflitos, com figuras de referência tais como Meyer Fortes e Evans-Pritchard. A entrevista ilumina essas tensões geracionais de forma primorosa.

Originário dos setores populares de Manchester, Keith Hart carrega o orgulho de quem chegou por seu próprio mérito na tradicional Cambrigde primeiro na escola, depois na universidade -, mas também guarda as marcas deixadas pelo sacrifício necessário para estar e se manter nesse espaço de 
elites e elitista, sem "precedente algum". Como ele mesmo diz, a experiência em Gana, em particular a vida dinâmica e pulsante do bairro popular onde realizou pesquisa de campo em Accra, o ajudou a dimensionar o conservadorismo e a hierarquia de Cambridge.

Além de ter sido professor na Grã-Bretanha nas universidades de Manchester, Cambridge, Norwick, Aberdeen, Londres (London School of Economics and Political Science), ensinou durante muitos anos nos Estados Unidos e na Jamaica, e criou e coordenou ao longo de mais de uma década um programa de pesquisas em Economia Humana na África do Sul. Desde I997, reside em Paris e tem realizado pesquisa, docência e consultorias em diversos países. A experiência de vida em todos esses lugares e a reflexão intelectual a partir deles constituem uma das características na sua forma de enxergar o mundo e a raiz de uma perspectiva comparativa implícita que potencia suas análises.

A entrevista também nos apresenta de forma detalhada o mundo das ruas e as práticas econômicas que embasam a discussão sobre informalidade, mostrando concomitantemente a participação do autor nesse universo, levantando importantes questões sobre as formas de conhecimento e a vida dos setores populares. Por outro lado, sua participação no mundo do desenvolvimento, como professor, consultor e analista, permite compreender a formulação e a circulação do próprio conceito. Em artigo publicado neste número, Fernando Rabossi analisa o contexto de surgimento do conceito de informalidade e sua trajetória institucional no âmbito da Organização Internacional do Trabalho, elementos que nos permitem compreender a difusão e popularização de uma noção que se institui como chave descritiva e normativa do mundo contemporâneo.

A participação do autor no mundo do desenvolvimento também é abordada a partir de um retrato inédito na elaboração do plano de desenvolvimento de Papua Nova Guiné no momento de sua independência, mostrando as tensões e as possibilidades abertas no cenário pós-colonial, atravessado por disputas entre mineradoras, governos, agências internacionais e diversos outros atores locais.

Combinando uma perspectiva baseada na antropologia econômica, na economia política e na história econômica, Keith Hart tem uma prolífica produção que inclui trabalhos sobre agricultura na África Ocidental (I982), migrações rurais-urbanas, dinheiro, mercantilização, mercados e história da antropologia econômica, bem como incursões pioneiras sobre o desenvolvimento do capitalismo digital (2000). A produção de Hart está ligada à renovação dos estudos sociais do dinheiro (I986), tendo produzido um olhar inovador tanto do ponto de vista analítico quanto das consequências políticas da monetização da vida social e da proliferação de moedas (2000). Seu artigo publicado na seção Registro de Pesquisa deste número apresenta suas principais ideias em relação ao dinheiro e ao envolvimento com movimentos sociais e com experi- 
mentações intelectuais. Essa trajetória é uma das entradas ao projeto Economia Humana, que busca articular formulações e alternativas econômicas em andamento ao redor do mundo, e que podem se constituir em alternativas ao modelo de desenvolvimento vigente (Hart, Laville \& Catani, 20ıo). Também neste número, o professor da East China Normal University (Shanghai) e pesquisador do CNRS (Université Paris-Dauphine) Horacio Ortiz analisa de forma detalhada a contribuição de Hart nos campos da antropologia das finanças e do dinheiro e da sociologia econômica.

Para compreender a afirmação do início desta apresentação sobre o caráter desafiador dos formatos institucionais da disciplina antropológica, destacamos duas iniciativas que mostram a criatividade e os engajamentos de Keith Hart, além daquelas descritas até aqui, como o projeto da Economia Humana. Em I993, junto com Anna Grimshaw, começou a publicar os Prickly Pear Pamplhets, inspirados na figura dos panfletos de ativistas radicais do século XVIII, em que apareceram textos que se tornariam clássicos como Waiting for Foucault, de Marshall Salhins (I993), e The Relation, de Marilyn Strathern (I995), entre vários outros. ${ }^{2}$ Em 2009, com alunos e colegas, criou a Open Anthropologist Cooperative, uma plataforma online que conta hoje em dia com mais de 18.000 membros.

A entrevista foi realizada em 23 de maio de 20 I I no Museu Nacional e foi revisada e modificada em 2018 por Keith Hart para publicação nesta revista. A tradução foi realizada por Ricardo Coelho Netto da Silveira e por nós revisada.

Federico Neiburg. Você fez seu PhD em antropologia em Cambrigde, tendo estudado antes latim e grego. Como você chegou à antropologia?

Keith Hart. Eu amava literatura clássica. Eu estava pronto para ser um crítico literário no estilo da disciplina, e, naquela época, $80 \%$ de toda a avaliação dos alunos era tradução. Eu amava tradução, em ambos os sentidos. Ganhei um prêmio uma vez por traduzir Dante em hexâmetro homérico. Mesmo agora, eu diria que a maior atividade intelectual é a tradução. Não entre línguas, mas no sentido de que cada vez que um de nós tenta se comunicar isso envolve algum tipo de tradução entre a sua experiência e a minha, e se alguma coisa realmente acontece é meio que acidental. O que eu amo da humanidade é a extraordinária boa vontade que trazemos para a comunicação, enquanto, na verdade, comunicamos muito pouco. Ainda assim, acreditamos firmemente que o que acabei de dizer está agora na sua cabeça. Retornando a sua questão, os clássicos eram muito restritivos naquele tempo. Eu estava interessado em tragédia grega e poesia lírica latina, mas não havia nenhuma chance de que eu pudesse fazer um $\mathrm{PhD}$ sobre esse assunto. O objetivo da crítica literária era consolidar a tradição, e a maioria dos principais autores já estava consolidada, 
pelo que estávamos presos a cultivar as margens. Outra questão era que brilhantes garotos ambiciosos faziam clássicos e matemática. Desse modo, em Cambridge havia todos esses garotos brilhantes como eu, que eram também fascinados por latim e grego. A competição era bastante substancial, embora o mercado de clássicos estivesse em declínio. Assim, fui sempre realista, eu aspirava fazer uma carreira profissional. Ao mesmo tempo, nos anos I960, as ciências sociais estavam se expandindo. Então eu pensei que seria melhor mudar de clássicos para ciência social. A primeira coisa que pensei, obviamente, foi sociologia.

F.N. Se pudéssemos ir um pouco mais para trás, como, de Manchester, você chegou em Cambridge?

K.H. A casa de minha família sempre foi em Manchester. Fui para a Manchester Grammar School, que era a melhor escola do país naquela época. Eu era especializado em clássicos. A Manchester Grammar School tinha uma bolsa, a Patchett, para St John's College, em Cambridge; um dia meu professor disse, "é claro que você receberá a Patchett". Isso significava que eu podia entrar em Cambridge sem passar pelos exames. Foi assim que entrei lá.

F.N. Eu ouvi você dizer que encontrava alguns paralelos entre Cambridge e uma igreja.

K.H. Quando tinha oito anos, fizemos uma viagem a Cambridge. "Por que tem tantas igrejas aqui?" perguntei, e eles me responderam "não são igrejas, são escolas". Eu disse "quando crescer, eu quero ir para uma escola que pareça uma igreja". Isso se tornou uma mitologia familiar. "Keith quer ir para Cambridge." Então, eu estava completamente fixado durante minha adolescência em passar para Cambridge.

F.N. Quem estava em Cambridge quando você chegou?

K.H. Meu treinador de remo (eu era timoneiro, dirigia um barco a remo de oito pessoas) era Claudio Vita-Finzi, um geógrafo de Turim, da aristocracia judaica. Ele costumava passar todos os invernos no mediterrâneo estudando a erosão do deserto, como as cabras fazem isso na Sicília ou no Líbano, e depois ele voltava na primavera para treinar remo e fazer suas coisas. Eu pensei, isso é muito bom, essa não é uma má maneira de viver. Depois ouvi que antropologia social era sociologia com viagens inclusas. Mas o que me decidiu foi Jack Goody, que era da minha faculdade, e ambos éramos bebedores regulares. Um dia ele disse que estava oferecendo um seminário sobre clientela, isso foi em I962, que era um tema bastante popular. Eu disse ao Jack que lhe entregaria um artigo sobre clientela em Roma. Depois esqueci. Um dia, ele disse, "lembre-se de que 
você está confirmado com seu artigo no seminário desta quarta-feira". Se eu estivesse escrevendo um ensaio sobre a clientela romana, eu teria que ler todos os textos existentes no original e construir o ensaio a partir de citações originais. Meu tutor não teria aceitado qualquer outra coisa. Mas eu não tinha tempo. Fui para a biblioteca e peguei o Cambridge Ancient History e algumas fontes secundárias e montei algo verdadeiramente vergonhoso, construído a partir de fontes secundárias, apenas lendo livros em inglês. E fiz essa palestra. Estava realmente preocupado. E eles adoraram, comentando: "isso é tão sofisticado, tão perspicaz". Pensei: essas pessoas não têm padrões intelectuais de forma alguma. Eles não veem que estou blefando. Eu era um estudante treinado profissionalmente, mas se eu fizesse antropologia eu poderia estudar qualquer coisa, porque os antropólogos podem levantar qualquer pergunta, sem limites; exatamente o oposto dos clássicos. Nos clássicos, o tipo de pergunta com que eu estava envolvido era: "esta letra em um manuscrito espanhol do século XII é um alfa ou um eta”. Era bem assim, delimitado, e as pessoas gastariam I5 minutos discutindo isso em um seminário. Havia um incrível senso de foco e especificidade. Eu percebi que a antropologia me permitiria fazer qualquer pergunta de que eu gostasse. E que não tinha padrões acadêmicos. [Risos.] Isso era brilhante.

Fernando Rabossi. Então, você mudou para a antropologia pelas mãos de Jack Goody?

K.H. Na verdade, Jack Goody foi o único professor com que tive uma relação mais pessoal, porque, quando mudei de clássicos para antropologia social, ele ficou responsável por mim na faculdade e se tornou meu orientador da graduação. Depois ele foi meu orientador no doutorado. Tive também uma relação próxima com Audrey Richards, porque ela era a diretora do Centro de Estudos Africanos e deu um curso sobre urbanização e migração na África, que era meu tema favorito. No início de minha carreira eu só queria trabalhar sobre migração. Na verdade, meu trabalho de campo do doutorado foi sobre migrantes para a cidade.

F.N. Quem eram seus colegas?

K.H. Johnny Parry, Caroline Humphrey, Enid Schildkrout que mais tarde trabalhou no American Museum em Nova York, várias pessoas. Porém, Meyer Fortes como chefe do departamento não sabia quem diabos eu era, porque eu nunca aparecia no seu seminário. Quando fui fazer pesquisa em Gana, decidi estudar os Tallensi, que era seu povo. Escrevi cinco cartas para ele antes que ele me respondesse. Anos depois ele me falou que achava que Jack Goody tinha me enviado para minar seu trabalho. Fortes tinha assumido a antropologia social de Cambridge em uma fase realmente medíocre e construiu o melhor depar- 
tamento do país. Mas, naquela época, com a expansão da sociologia, tinha um novo departamento de ciências sociais e políticas, e Jack apoiava a integração da antropologia social a esse departamento. Meyer queria que a antropologia social permanecesse como era e sabia que Jack seria seu sucessor como chefe de departamento. Jack estava escrevendo artigos em revistas nacionais dizendo, "que seria a antropologia social se não fosse sociologia comparativa?". Então, Meyer era profundamente desconfiado do meu papel nesse jogo. E ele levou um longo tempo para superar suas suspeitas.

F.N. Qual era sua relação com Audrey Richards?

K.H. Eu sempre permaneci próximo de Audrey. Ela era uma ótima fofoqueira. Ela me disse uma vez que Jack tinha perguntado a ela sobre o que eu estava escrevendo em minha tese, porque ele nunca tinha lido. Eu estava convencido de que eu não tinha aprendido nada com ele. Muitos anos depois, ele lançou sua série de livros comparando a Eurásia e a África, o primeiro se chamava Production and reproduction e tem um pequeno prefácio, em que ele enuncia os princípios de sua abordagem. Li o primeiro e disse "sim, eu concordo com isso". Em seguida, no segundo, eu disse "eu concordo com isso". No terceiro, também concordei... Pensei, não pode ser acidental que eu realmente partilhe dos princípios de Jack Goody, no final das contas, talvez ele tenha me ensinado. Mas essa era a nossa geração, os anos I960, quando todos nós pensávamos que éramos órfãos, que não devíamos nada a nossos pais e professores, que estávamos construindo o mundo do começo, por nós mesmos. Finalmente percebi que Jack tinha me moldado. De fato, todo o trabalho que estou fazendo vem de uma tentativa de ser como Jack. Ele me ensinou pelo exemplo, mesmo que eu não estivesse consciente do que estava aprendendo concretamente com ele.

\section{F.R. E Meyer Fortes?}

K.H. Ele foi o examinador interno da minha tese de doutorado e foi muito, muito positivo. Me ofereceu um pós-doc no King's College para estudar os Tallensi com ele. Disse que eu seria o próximo professor em Cambridge e que poderia ensinar economia primitiva e camponesa, como Raymond Firth. Isso era muito assustador para mim. Eu pensei que fosse terminar nesse círculo restrito de "ganalogistas", no qual não havia intenção de generalizar porque todos sabiam as mesmas coisas locais. Em vez de aceitar sua proposta, aceitei um emprego em estudos do desenvolvimento em uma nova universidade, East Anglia, em Norwich. Meyer nunca me perdoou por isso. Contaram-me depois que ele foi a Chicago e alguém perguntou "alguém estudou os Tallensi depois de você?", e ele disse: "Bem, tinha um cara, mas ele desistiu de tudo para estudar turismo nas Antilhas”. A mim disse muito explicitamente que pensava 
ser o dinheiro a única razão pela qual eu estava fazendo isso e que eu era apenas mais um desses tipos utilitários de Manchester, interessados exclusivamente em análise de custo/benefício. Uma vez, ele me escreveu uma carta de sete páginas em que dizia: "Sempre achei que você fosse um benthamita com qualidades hedonistas. Eu não esperaria que alguém superficial como você entendesse a noção de piedade familiar." Coisas desse tipo. Ele realmente me matou. Nessa altura, eu pensei que não haveria nenhum modo de escrever sobre os Tallensi por intermédio de Fortes. Decidi, então, mudar para o tema do desenvolvimento para não entrar em competição direta. Ele interpretou essa recusa como meu desejo de ficar rico entrando para o Banco Mundial. Há uma conclusão para essa história. Eu estava lecionando em Chicago pelo período de um ano e recebi um cartão-postal de Meyer Fortes. Eu tinha publicado um artigo na série Research in Economic Anthropology sobre as condições econômicas da história social dos Tallensi no período colonial (Hart, I978). E basicamente tomei o lado de Fortes no seu debate com Leach e Worsley acerca das condições econômicas do parentesco. É um bom artigo, eu diria. É o único artigo que publiquei sobre os Tallensi. De alguma forma, ele o conseguiu e me enviou um cartão com a pintura Adoração dos Magos, de Rubens, que está na capela do King's College. Nele, me escreveu: "Eu estava errado sobre você, Keith. Você era sério, afinal. E você deu uma contribuição original para a análise econômica do norte de Gana". Tudo está perdoado, em outras palavras. Mas quando recebi esse cartão, ele estava morto. Ele havia escrito do hospital, e quando tentei entrar em contato com ele, me disseram "Oh, Meyer Fortes morreu na semana passada”. Você pode imaginar uma coisa dessas?

F.N. Foi uma relação intergeracional complexa...

K.H. Sim, de certa forma. Eu tenho a forte sensação de que Fortes e Evans-Pritchard pensavam que todos nós, minha geração, éramos uma perda de tempo. Que não havia como nos levar a sério, porque nós tínhamos nossa própria agenda, não estávamos escutando, apenas queríamos virar tudo de cabeça para baixo. Então eles cultivaram o fato de ser conservadores. Meyer manteve esse registro comigo ao longo de dez anos. Não consegui ter uma conversa séria com ele. Entendi mais tarde o porquê, porque ele achava que eu era um espião de Jack Goody. Jack naquele tempo encorajava todos os seus estudantes a estudar fenômenos sociais modernos: ensino, governo local, comércio. Meyer Fortes sentia que eu também estava do outro lado: nós éramos os modernizadores, nós não nos importávamos muito com a estrutura social tradicional. Um dia, eu lembro disso muito vividamente, Fortes me levou para almoçar. Nós falávamos não lembro sobre o que, e usei a palavra "tempo", e ele perguntou: "o que você quer dizer com 'tempo'?". Em dois minutos, estava imerso, quero dizer, estávamos em águas filosóficas e científicas realmente profundas. Meyer Fortes inventou esta- 
tísticas psicológicas com Karl Pearson. Conhecia Freud e Marx de trás para a frente. Evans-Pritchard era um mestre em filosofia e história racionalista inglesa. Eles decidiram enviar os estudantes para fora, para fazer trabalho de campo, mas não esperavam que entendessem alguma coisa. Fiquei muito chateado porque eles não ensinaram a história intelectual da disciplina que eles tinham dominado, mas eles não achavam necessário compartilhar isso conosco. Se me tornei um historiador intelectual - muito do que eu escrevo é sobre história intelectual, na verdade - é porque eles nos negaram o acesso a isso. Claro que, porque Meyer Fortes foi tão rude comigo, eu acabei venerando-o, porque você precisa ser duro comigo para obter o meu respeito, e ele o fez. Ele era realmente um cretino. Comecei a escrever um livro de memórias a respeito dele, e a primeira parte foi um artigo sobre seu trabalho publicado em I940. O melhor trabalho dele focalizou o ciclo de desenvolvimento em grupos domésticos: ${ }^{4}$ como se pode ter uma ordem social quando ela é baseada na vida, nas pessoas, nascimento, copulação, morte? é tudo tão caótico. A ideia é que as formas são impostas nos rituais do ciclo da vida, casamento, funerais e assim por diante. Ele uma vez me contou que tomou a ideia de D'Arcy Thompson, um cientista dedicado à forma e ao desenvolvimento, autor do livro On growth and form", que é antidarwinista. O argumento é: “Ok, evolução é sobre microvariações, mas se isso é tudo, por que todos os membros de uma espécie se parecem? Por que você pode falar que uma folha de carvalho se parece com todas as outras? O que é responsável por essa consistência da forma?" Esse era o negócio do Meyer. Ele costumava dizer, quando éramos estudantes, "vocês, tudo o que vocês querem é a mudança, mas o que importa é a continuidade. Essa é a parte difícil". Por que as espécies são tão estáveis em suas formas? Se a evolução se sustenta na variação, como a forma persiste apesar do fluxo da vida? O livro The web of kinship, que é bastante estatístico e baseado em redes, e especialmente o trabalho sobre os Ashanti, Time and social structure, foram os seus maiores feitos. Eu gostaria de escrever um livro sobre isso, porque é aí que sua formação científica e seu trabalho de campo se juntam. Suas notas de campo são incríveis. Ele ouvia as palavras de forma muito mais sutil do que eu... ele entendia a etimologia. Muitas de suas notas de campo são escritas em talni, e sua compreensão da língua era incrível.

F.N. Quando você começou a pensar em ir para a África?

K.H. Realmente acreditava, como eu acho que muitos de nós pensávamos naquela época, que a política pós-colonial tinha uma importância global. Fui para lá com um projeto político em mente. Estava indo para estudar migrantes para a cidade e para olhar sua relação com a política, com a cidadania, formas de associação, e assim por diante. Mas quando cheguei lá descobri que era um Estado policial, ninguém falava sobre política porque estavam todos com me- 
do. Então eu tive que repensar meu tema. Notei quão viva era a economia de rua, então decidi estudar isso. Mas fui para lá sobretudo com uma agenda política. Gana era importante porque foi o primeiro país africano a declarar independência. Havia muito mais disponibilidade em Gana, porque foi o epicentro da revolução anticolonial.

F.R. Foi nesse contexto que você começou a formular suas ideias sobre informalidade. Como esse assunto se desenvolveu no início de seu trabalho em Gana?

K.H. Por volta de I970, tornou-se muito claro para todos que o boom de pósguerra tinha acabado. O projeto de desenvolvimento para fazer com que os países pobres ficassem ricos tinham falhado. Esse foi o momento em que a teoria do subdesenvolvimento, a teoria dos sistemas mundiais, a teoria da dependência e assim por diante foram todas aparecendo na América Latina e no Oriente Médio, e havia uma espécie de pânico nos Estados Unidos, especialmente em instituições como o Banco Mundial, quando notaram que as cidades do Terceiro Mundo estavam crescendo muito rápido, mas nelas não parecia existir qualquer emprego real. Quem tinha emprego real era uma porção muito pequena do número total de pessoas que tinham vindo para viver na cidade. Então, eles imaginavam que as pessoas que não tinham empregos estavam desempregadas no modelo da década de I930, homens quebrados perdendo empregos na fábrica, parados nas esquinas. Havia um medo do desemprego como desestabilizador, como uma fonte de rebelião ou revolução. Essa era a problemática por volta dos anos I970. Quando entrei nos estudos de desenvolvimento como o único antropólogo, todo mundo estava falando sobre o que fazer com o problema do desemprego. Alguns defendiam enviar de volta para o campo aquelas pessoas, onde poderiam causar menos danos. Esse era o contexto. Eu pensava, “desemprego?" Finalmente me dei conta de que elas não estavam desempregadas, elas estavam trabalhando! Estavam trabalhando de uma maneira que não era reconhecida pelos funcionários do Banco Mundial. Então escrevi para dizer que essas pessoas tinham muito mais à sua disposição do que parecia. Só porque não tinham empregos formais não significava que elas não tinham nada (Hart, I973). Peguei do Weber a ideia de que formal queria dizer regular, regrado, e que informal significava irregular, não sujeito a regras. Mas, desde o início, percebi esses conceitos dialeticamente interconectados.

F.N. De quando é seu primeiro trabalho ou primeiro artigo sobre esses temas?

K.H. Eu o produzi em Sussex, em I97I, para uma conferência sobre desemprego urbano na África. Dois economistas organizaram a conferência: Richard Jolly e 
Hans Singer. Meu trabalho foi um grande sucesso. Mas esses economistas se mantiveram indiferentes a ele. Dizia-se que haveria um livro sobre a conferência. As mesmas pessoas foram para Quênia e produziram um relatório para a OIT em I972, cujo argumento principal era a importância do setor informal, como eles o chamaram. E não fizeram nenhuma referência a mim. Logo depois eles anunciaram que haviam cancelado o livro da conferência. Algumas pessoas que tinham estado na conferência começaram a escrever artigos dizendo "Keith Hart inventou o setor informal". O editor do Journal of Modern African Studies, David Kimball, me escreveu dizendo: "se você me der o trabalho, vou publicá-lo rapidamente". Foi o que ele fez. O trabalho foi publicado em I973. O relatório da OIT teve como objetivo algo diferente do meu. Meu objetivo era usar minha experiência etnográfica para corrigir falsas impressões sobre o que as pessoas estavam fazendo. Eu não estava interessado em inventar um conceito. Só queria que os economistas do desenvolvimento reconhecessem que estava errado o modo como eles imaginavam que as pessoas estavam trabalhando. Os outros queriam um conceito burocrático. Assim, a ideia teve uma dupla procedência, burocracia e as pessoas, economia e etnografia. Nessa época me converti ao marxismo, e os marxistas odiavam o setor informal, que preferiam chamar de pequena produção mercantil. Então deixei isso de lado durante i5 anos. No final da década de I980, quando o mundo estava mudando - o muro de Berlim, Mandela etc. - me perguntei o que teria acontecido com a questão informal. Ela ainda estava bem forte. E achei que era hora de reestabelecer a propriedade. [Risos]

F.N. Naquele tempo, você sabia alguma coisa sobre antropologia do desenvolvimento e a sociologia na América Latina? Por exemplo a monografia escrita em I975 por Larissa Lomnitz Cómo sobreviven los marginados? (Lomnitz, I993).

K.H. Conheci Larissa Lomnitz pessoalmente, mas não tinha lido seu livro nessa ocasião. Havia muitas pessoas escrevendo nessa época. Clifford Geertz escreveu sobre a economia de bazar em I963 (Geertz, I963). Havia um geógrafo chamado Terry McGee, que trabalhou no Sudeste Asiático, que publicou um livro em torno de I97 I, lançando mão de Geertz para falar sobre a economia empresarial e a economia de bazar (McGee, I97 I). Foi o momento em que eles perceberam que a modernização não funcionava. Então, o que, diabos, está acontecendo? Também era o momento em que os americanos estavam perdendo a guerra no Vietnã, o regime de pós-guerra de Breton Woods colapsou, esse foi o ponto de mudança do mundo moderno. Depois, em I973, foi a Guerra de Yom Kippur, a Opep, o aumento do preço do petróleo, a crise energética. Esses primeiros anos da década de I970 foram realmente um enorme ponto de virada. O neoliberalismo, como o chamamos hoje, foi o que aconteceu depois disso. Levou o resto dos anos I970 para se resolver, mas no final dos anos I970 Thatcher e Reagan estavam no poder. 
F.N. Como foi fazer trabalho de campo em Gana naquela época? Foi uma experiência muito original naquela ocasião. Como você conseguiu fazer trabalho de campo sobre migração, economia rural e urbana no meio dos anos I960? Você já escreveu sobre seu trabalho de campo, não é?

K.H. Sim, em 2005, o texto Africa on my mind (Hart, 2008). Tenho sido um apostador profissional desde os meus 12 anos. Estive muito envolvido com corrida de cavalos em Cambridge. Entrei no submundo de Cambridge por intermédio do gerente de cozinha da minha faculdade. Nossa amizade surgiu dos cavalos. Naquela época o submundo de Cambridge estava construído, principalmente, em torno da comida, o que queria dizer que os gerentes da cozinha roubavam a comida das faculdades e a vendiam para os donos de restaurante cipriotas. Esse era o elemento principal. Havia também um novo tipo de máfia italiana, baseado na construção, cimento e pizza. Também tinham os trapaceiros das corridas de cavalos, além da polícia, claro, a polícia sempre está envolvida. Costumávamos nos encontrar em um clube de strip-tease na Newmarket Road. Jack Goody queria que eu estudasse as corridas locais. Eu sabia que poderia acabar morto e disse: "de jeito nenhum, eu não vou fazer isso". Porém, eu também cresci em uma parte de Manchester onde ninguém poderia esperar que a polícia fosse o exemplo dos princípios da lei e da ordem. Eles eram violentos e corruptos. Com oito anos de idade, eu estava pegando doces de pedófilos sem ir para os arbustos com eles. Esse era o tipo de mundo em que eu cresci. Então eu fui para as favelas de Accra porque os Frafra estavam lá. ${ }^{5}$ Um pequeno gângster me ofereceu moradia e me levou para a casa dele. Minhas primeiras semanas foram muito difíceis porque ninguém parecido comigo tinha vivido nesse tipo de lugar, e eu tinha a polícia secreta, seis deles, me vigiando permanentemente. Eles batiam nas pessoas com que eu conversava para tentar descobrir o que eu realmente estava fazendo ali. Toda aquela região pertencia às "terras ruins" que a polícia invadia ocasionalmente com caminhões, armas e cães. Eles ameaçavam as pessoas e iam embora. Aí vinham as acusações de bruxaria: quem foi que deu a informação? E eles acabavam apontando para mim por ser de fora, o homem branco. Aquilo foi ficando fora de controle. Fui até um professor de sociologia da universidade para pedir-lhe uma carta dizendo que não era da CIA. Ele disse: “como eu vou saber que você não é?”. Então foi ficando perigoso. Eu decidi que deveria cruzar a linha. Não podia mais ficar em cima do muro. Com o objetivo de fazer essas pessoas perceberem que eu estava do seu lado, eu tinha que ser tão vulnerável quanto eles eram. Então decidi me tornar um fora da lei e me associei ao meu locador. Ele estava sempre sem dinheiro, e eu tinha minha bolsa, que, naquelas circunstâncias, era bastante coisa, e então botei o dinheiro num empreendimento, ele fornecia os contatos e o conhecimento, dividíamos o lucro 50-50 e eu obtinha minhas notas de campo. Como você descobre sobre o empréstimo de dinheiro se você não é 
um agiota? Eu já tinha lido muitas coisas estúpidas de antropólogos sobre o empréstimo de dinheiro (Hart, 2017). Eles sempre falavam sobre quão grande é a taxa de juros, mas a questão é a taxa de inadimplência: como você recebe o dinheiro de volta das pessoas? Nenhum agiota vai falar para você sobre inadimplência porque ele deve fingir que nunca acontece. Eu descobri a maioria dessas coisas fazendo-as. Vou lhes dar um exemplo. Decidimos ir ao campo com o proprietário do meu apartamento, que não sabia nada do campo, para comprar grãos pensando na escassez no futuro. Notamos que o preço era mais baixo na época da colheita, em setembro, e em março o preço dobrava. Então pensamos, o que poderia ser mais fácil? Nós compramos um monte de sacos de milho e os vendemos seis meses depois pelo dobro do preço. Nós compramos 50 sacos de milho. Os carregadores na parada de caminhões cobravam 5 xelins por saco somente para tirar um saco do caminhão. Depois havia outros custos, como mexer o grão, caso contrário ele pega besouros. E tem que comprar inseticida. Manter milho por seis meses nos trópicos não é brincadeira. Quando havíamos conseguido dar conta de tudo isso e estávamos prontos para vender, os americanos despejaram milho no país como ajuda e levaram o preço de volta ao nível da colheita. [Risos.] Se tivéssemos sorte, nós ganharíamos o que pagamos por isso. Porém, nós tivemos todas essas outras despesas no meio. A única forma de fazer alguma coisa era por meio da venda a crédito. Mas, como você consegue receber o dinheiro de volta? Você tem que mandar algum cara para quebrar algumas pernas [Risos] e ele precisa ser pago, e assim por diante. Assim é que funciona. Eu não sei como você pode fazer trabalho de campo nessas áreas sem ser parte ativa disso.

F.N. Por quanto tempo você fez trabalho de campo em Accra?

K.H. Dois anos e meio. Eu não fiquei só em Accra. Também passei um tempo no Norte. Fiquei vários meses na aldeia em que Meyer Fortes trabalhou. E também fui preso quatro vezes: duas pelo Exército e duas pela polícia. Uma delas foi realmente difícil. Eu escrevi sobre isso naquelas memórias (Hart, 2008). Tive que pensar muito sobre como se faz um suborno. Você já pensou sobre isso? Não é apenas jogar dinheiro na mão de alguém que te pede. Você tem que achar alguém grande o suficiente para controlar os peixes miúdos, mas que não seja muito caro. No British Colonial Police Service esse era o superintendente assistente da polícia. Ele era o cara que controlava os peixes pequenos e recebia os subornos. Nesse momento, estávamos reciclando drogas apreendidas pela polícia para voltar ao mercado. Algumas vezes eu tinha cinco libras de maconha no teto do meu quarto. Eu estava sob pressão constante vinda de soldados e da polícia, e decidi me proteger guardando os registros do maior nível de corrupção que eu conhecia. Escrevi isso em triplicatas e enviei para minha mãe, que pirou quando leu aquilo tudo. [Risos.]

F.N. Você foi preso pelo Exército, não? 
K.H. Fui preso pelo Exército depois do golpe contra Nkrumah; eles me pegaram por um final de semana e enfiaram uma baioneta na minha perna, pisotearam minhas mãos e quebraram minhas unhas. Tudo que eu conseguia pensar era, "eu espero que isso não signifique que o meu $\mathrm{PhD}$ vai ser adiado!". É difícil imaginar quão carreirista acadêmico eu era. Eu não podia pensar em outra coisa para minha vida que não fosse me tornar um acadêmico. Mas, da mesma forma, eu não queria depender da academia. Então, eu fiz essa série de coisas. Trabalhei para The Economist, para o Banco Mundial, tive a opção das apostas, especulei em habitação...

F.N. Oportunidades formais e informais de ganhar a vida. [Risos.]

F.R. Você mencionou uma conversão marxista, mas trabalhou para o Banco Mundial... Como foi trabalhar para o Banco Mundial?

K.H. Foi ótimo, na verdade. O grupo de Norwich para o qual trabalhava foi contratado para escrever um programa de desenvolvimento para a independência da Papua Nova Guiné [PNG] com o Banco Mundial como agente do Programa das Nações Unidas para o Desenvolvimento e para o governo da Austrália. Éramos quatro. Um estava encarregado da estratégia financeira e de desenvolvimento, outro estudava agricultura, outro estudava mineração, e eu tinha o resto - trabalho, política social, educação, desenvolvimento rural, tudo isso. Nós ficamos na Papua Nova Guiné durante três meses e também paramos na Austrália. Foi uma época muito interessante porque o governo da coalizão do Partido Liberal e do Partido Nacional tinha estado no poder ao longo de 23 anos, e era amplamente esperado que o Partido Trabalhista sob Gough Whitlam pudesse chegar ao poder. Havia a sensação de as coisas estarem virando. Foi uma experiência maravilhosa, que nos levou por toda parte. Eu fui para as ilhas Trobriand, Nova Irlanda, o rio Sepik, Goroka, as terras altas da Nova Guiné, foi como um tour na antropologia clássica. Mas nos metemos em um conflito; naquela época, a mina de cobre de Bougainville era a maior mina de ouro do mundo. Era gerida por uma subsidiária australiana da Rio Tinto Zinc, e aquilo era um roubo completo. PNG poderia ter sido outro Congo, pois já tinha tido três movimentos de secessão: um em Bougainville, um em Nova Irlanda, e o terceiro em algum outro lugar. Mike Faber (o líder da equipe) e eu sentíamos que se a Papua Nova Guiné iria ter alguma chance, eles tinham que maximizar seus retornos de alguns enclaves de exportação: mineração, silvicultura, pesca etc. e usar o dinheiro para incluir a periferia rural por meio de redistribuição. Essa foi a política no geral. Mas essa mina da Rio Tinto estava fomentando ativamente a rebelião lá, tal como a União Minière em Katanga. A diferença era que os franceses, os belgas e os americanos apoiaram a União Minière, mas o governo australiano via a Papua Nova Guiné como a sua fronteira do Pacífico. A última coisa que eles queriam era que se fragmentasse em um monte de ilhas administradas por empresas multinacionais. Então, eles disseram para 
Conzinc Riotinto of Australia, "se vocês não ficarem espertos e seguirem nossa linha, nós vamos confiscar suas minas de níquel em Queensland”. Em outras palavras, "temos maneiras de impedir vocês de minerar na Austrália, que é a sua base". Então tudo mudou muito rapidamente. A ideia da integridade da Papua Nova Guiné foi realmente um dos grandes pilares da política australiana, e não havia sido para os poderes imperiais no Congo. A mina de Bougainville não estava dando receita ao Estado como deveria. Tinha sido um regalo. Então nós insistimos na renegociação do tratado. Nesse ponto, os outros dois caras, os especialistas em agricultura e mineração, renunciaram porque achavam que suas carreiras como consultores estavam indo para o espaço. O Banco Mundial estava contra nós, o Departamento de Territórios Externos e a administração colonial também. Todo mundo estava contra nós. Mas nós não teríamos ficado a menos que alguém nos apoiasse. Faber era conhecido por ter inventado a nacionalização do $51 \%$ do cobre na Zâmbia da Anglo-American. Então, por que nomear alguém cuja fama foi construída a partir da nacionalização do cobre, quando todos os interesses consolidados em PNG pareciam estar contra isso? O cara do Banco Mundial era o mais hostil a isso tudo. Isso foi tão ruim, que eu peguei bronquite. Atravessei uma porta de vidro no hotel e quebrei meus óculos [Risos]; daí tive que usar meus óculos escuros. Eu dificilmente conseguia falar, era uma mistura de tosse, estava usando óculos escuros e estava rouco, tive que defender nossas recomendações contra todos. Uma tarde, no bar, um cara vem até mim e diz: "Deixe-me pagar uma bebida Keith, você está fazendo um grande trabalho". Descobrimos que toda a inspiração para a missão veio do Tesouro australiano, e ele era seu principal funcionário. Papua Nova Guiné era um instrumento para reciclar impostos australianos para três grupos de interesse: os funcionários públicos, os comerciantes e os fazendeiros, porque eles estavam despejando excedentes de produtos lácteos e arroz na Nova Guiné - é daí a coalizão Liberal-Partido Nacional... O Departamento de Territórios Externos sempre esteve na mão do Partido Nacional, que era o partido dos fazendeiros. Não parece muito agora, mas 500 milhões de dólares australianos de impostos estavam sendo desviados para esses três grupos por intermédio de Papua Nova Guiné. O Departamento do Tesouro da Austrália decidiu tornar Papua Nova Guiné independente e acabar com esse acordo de compadres. Então nossa política de dizer para renegociar o acordo de mineração em Bougainville, conseguir o máximo de dinheiro que puder, usar o dinheiro para fortalecer a integridade territorial do país, construir relações de clientela com a periferia, tudo isso era exatamente o que os caras do Tesouro queriam. Acontece que eles, na verdade, nos nomearam. Mas nós nunca soubemos que tínhamos amigos em algum lugar. Nos cinco anos seguintes, desde a publicação de nosso programa, os líderes dos três movimentos separatistas estavam no gabinete nacional! Produzimos um relatório preliminar entre viagens, e eles tiveram eleições para estabelecer o autogoverno. Pan- 
gu, o partido vencedor, tinha divulgado algo chamado "Os oito pontos de desenvolvimento", que tinham tirado do nosso relatório preliminar. Quando voltamos, Faber e eu nos encontramos com Michael Somare, o novo primeiroministro. Ele disse: "Senhores, obrigado. Antes de vocês chegarem, fomos informados pelo Banco Mundial e outros que o desenvolvimento significava apenas uma coisa, incrementar a renda monetária daqueles que mais têm. Agora sabemos que há, pelo menos, um outro método". E nesse momento, o cara do Banco Mundial e o diretor de planejamento do governo colonial apareceram, "essas pessoas estão apenas falando o que nós estivemos falando o tempo todo [Risos] e nós esperamos que você nos dê a tarefa de implementar o seu programa de desenvolvimento".

F.R. Essa foi a época em East Anglia, não foi? Você permaneceu por lá?

K.H. Não, eu fui para Manchester e lá dei aulas durante quatro anos. Eu também trabalhava como consultor de desenvolvimento e, em meia jornada, para o The Economist. O incrível é que Manchester não tinha ninguém para ensinar antropologia urbana. Isso devia ser em I97I. Eu estava indo bem, estava casado, tive um filho, minha mulher tinha um emprego em uma universidade próxima, tínhamos uma ótima casa. E então aconteceu algo que me levou a brigar com o chefe do departamento, Ermys Peters. Então, a esse ponto, eu escrevi para quatro universidades americanas: Yale, Harvard, Chicago e Northwestern para dizer que eu estava disponível no mercado. Fui entrevistado em Yale e Chicago, e ambas me ofereceram emprego. Em Yale eles disseram, "nós queremos nomeá-lo professor-associado. Mas, não sabemos se com ou sem tenure". ${ }^{6}$ Eu disse: "vocês devem estar brincando se pensam que eu vou atravessar o Atlântico sem tenure". Eu não tinha um livro publicado ainda, não tinha escrito nada exceto esse artigo sobre a economia informal. Mas eles me deram o tenure. Eu achava que o tenure fosse o que era na Inglaterra - você arruma um emprego, trabalha por dois anos e consegue o tenure. Mas em Yale, é questão de vida ou morte, mas eu não sabia nada dessas coisas. Fiquei por lá até 1979.

F.N. Como foi a sua experiência nos Estados Unidos?

K.H. Foi a época mais difícil da minha vida, porque minha família se separou, surtei várias vezes, renunciei e tive que me vender em contratos de curto prazo. Foi muito, muito difícil. Eu amo a América. Eu sou um grande fã da sociedade e da cultura americana. Mais tarde transferi esse afeto para o Brasil, mas nesse momento a América preenchia meu anseio por bom esporte, boa música popular, boa comida. Um país surpreendente, grande e diverso. Quando surgiu a oportunidade de ir para a América, eu queria aceitar a oferta, mas minha esposa não queria. Depois de três meses de angústia, eu escrevi duas 
cartas, uma dizendo sim, outra dizendo não. Eu coloquei um selo nas duas e levei ambas para o correio, eu enviei uma delas e rasguei a outra. A que eu enviei dizia sim. Mas eu sentia um grau de compulsão para ir que eu nunca havia experimentado antes ou desde então. Uma sensação de que toda minha vida dependia de ir para lá naquele momento. Retrospectivamente, eu acho que não é difícil de entender. Os americanos desenvolvem isso em você. Eles dizem, "Ok garotão, mostre-nos suas coisas. Faça o que você gosta, você está aqui, você é nossa estrela, vá fundo". E você pensa, "é foda, não é como a Inglaterra". Na Inglaterra, eles diriam, "menos, garoto”. [Risos.] Então, eles te dão um grande estímulo. Mas quando as coisas não funcionam, não há ninguém lá. Me lembro de estar em uma esquina em Chicago e o vento estava entrando nas minhas entranhas, era inverno, e eu pensei, "não há ninguém em I500 milhas que me entenda". Eu estava completamente sozinho. Esse era o outro lado da moeda. Por um lado, você vai para lá, faz o que gosta. Depois, se você se quebra, você está por sua conta. Por muitos anos, a Inglaterra me deprimia, me deixava para baixo, a América me estimulava. Mas por outro lado, eu estava sozinho na América e quando voltei à Inglaterra foi muito confortável ter pessoas a minha volta que me conheciam e eram próximas de mim. Então eu voltei para Cambridge e logo consegui um emprego como professor-assistente. Com 32 anos tinha um tenure em Yale, com 4I estava começando como professor-assistente na base da hierarquia, sem estabilidade e com um salário muito baixo.

F.N. Foi nessa época que você escreveu o artigo sobre dinheiro? Eu vejo muitas conexões entre a sua etnografia em Accra e o seu trabalho sobre dinheiro, começando pelo artigo sobre os dois lados da moeda (Hart, I986).

K.H. Isso foi um pouco mais tarde, na minha primeira década de volta a Cambridge, nos anos I980. Até certo ponto, o par Estado/Mercado no meu artigo sobre dinheiro, é um primo do formal/informal. Há uma lógica hegeliana que eu gosto. Nenhuma ideia é abarcadora ou forte o suficiente para dar conta do que as pessoas realmente fazem. Sempre há esse desborde. Ainda, e continuando com Hegel, a mais poderosa ferramenta analítica ocorre quando a grande ideia produz, como sua negação, outra ideia que deve captar o que esta não é. Entre elas, obtém-se um pouco mais desse todo, mas ainda não tudo. Então essa ideia de caras e coroas, Estados e mercados veio no início do período neoliberal, quando Friedman havia derrubado Keynes; então havia uma sensação dessa oscilação louca entre administração estatal do dinheiro e sua liberação. A palestra’ tinha (como tem o artigo) três seções, e essa organização era a principal mensagem para mim: "Nós estamos aqui para celebrar Malinowski, e Malinowski nos deu um gênero particular de trabalho etnográfico, do qual todos nós temos vivido, de certa maneira". Mas na primeira seção, digo 
que os antropólogos têm de ser mais conscientes sobre a história do mundo do qual nós fazemos parte, como essa passagem de Keynes para Friedman. Isso tem que influenciar aquilo que nós pensamos sobre o dinheiro. Então, mesmo se apenas ingenuamente, nós temos que nos engajar no mundo em que estamos vivendo e refletir como isso influencia as questões que formulamos. Em segundo lugar, nós não podemos entrar em disputas econômicas usando ideias reducionistas vulgares, como o Homo Economicus, tal como Malinowski fez, quando a história monetária é muito rica e variada e há alternativas bem desenvolvidas para olhar. Não é muito difícil descobrir quais são elas. Nesse sentido, History of economic analysis, de Schumpeter (I954) é bastante legível. Eu argumento que, em vez de brigar com as versões usuais das ideias econômicas ocidentais, deveríamos ser capazes de aprender com algumas delas. Existe a história do dinheiro estatal, do dinheiro comunitário, do dinheiro de mercado e assim por diante. Vamos ver se podemos colocá-las juntas em um conjunto, em vez de ir de um extremo para outro. A terceira seção dizia, "se nós olharmos para o que os economistas têm para nos oferecer e pensarmos um pouco sobre o nosso lugar na história, podemos produzir uma análise mais sofisticada sobre as ilhas Trobriand do que a de Malinowski, analisando de cima para baixo e de baixo para cima as formas de organização dos intercâmbios de peixes e inhames, por exemplo. Essa era a mensagem. Mas essa parte da palestra nunca foi realmente considerada. Jane Guyer, Robert Foster e alguns outros parecem ter captado a mensagem. Mas eles nunca adotaram as duas primeiras seções, com suas sugestões de que nós temos que ter uma visão histórica que é contemporânea e que devemos passar mais tempo com os especialistas. Você não poderia estudar direito sem dar atenção à história da jurisprudência. Por que você pensaria que pode estudar os mercados e o dinheiro sem dar atenção à economia? Mas muitos antropólogos não o fazem. Johnny Parry e Maurice Bloch (I989) produziram o seu Money and morality of exchange um pouco mais tarde. Eu provavelmente exagerei o contraste entre o que eu faço e o projeto deles, mas eles pensavam que estavam fazendo algo similar. Em seu livro, as pessoas nas sociedades não capitalistas ao redor do mundo não são reféns do dinheiro no mesmo grau como nós estamos em sociedades capitalistas; e eles colocaram o dinheiro para o uso de longo prazo como reprodução social. Tudo bem. Mas o que eles não consideram é como e por que o dinheiro passou supostamente a ter vida própria nas sociedades capitalistas. Por que é que o pagamento em dinheiro transforma uma relação para nós? Eles não abordam isso. Johnny é meu melhor amigo, nós criamos nossas filhas adolescentes juntas. Demos as palestras Malinowski consecutivamente, e elas foram publicadas no mesmo ano; a dele, sobre a dádiva indiana (Parry, I986), é mais famosa do que a minha. Na Conferência Mauss vivant, em Cerisy, ${ }^{8}$ falei que estava indo com Johnny Parry, e eles disseram: "você quer 
dizer “o" Johnny Parry? Da dádiva indiana?" Eu pensei que meu livro The memory bank (Hart, 200o) era significativo, mas dez anos mais tarde percebo que qualquer coisa que eu escrevi não é tão importante quanto o artigo de I986. Tem alguma coisa realmente profunda lá, de que, provavelmente, não estava ciente. Ainda ganho mais o revisitando do que voltando para meu livro.

F.N. Eu sou fascinado pelas conexões entre o artigo sobre cara e coroa (Estado e mercado) e seus desenvolvimentos posteriores sobre o tema do dinheiro e dos negócios que, como você diz, são sempre pessoais e impessoais. O que você pensa sobre essa ligação?

K.H. Continuo voltando a essas perguntas, mas os termos nos quais as coloco mudam, se alimentando daquilo que havia escrito anteriormente. Assim, nos últimos dez anos, como resultado de The memory bank, o par-chave para mim tornou-se pessoal/impessoal. O pequeno livro The hit man's dilemma (Hart, 2005) é minha mais completa tentativa de explorá-lo. Mas sim, certamente, há um envolvimento persistente com pares dialéticos que podem nos ajudar a entender algumas perguntas persistentes. Torna-se difícil separá-los. É formal/informal, pessoal/impessoal, Estado/mercado, virtual/real? Acredito que a razão fundamental pela qual eu sou antropólogo vem da minha experiência como adolescente tentando passar nos exames para entrar em Cambridge. Não podia suportar o sistema de avaliação impessoal. Primeiro de tudo, eu não tinha nenhum apoio familiar. Meus pais estavam muito orgulhosos de mim, mas eles não podiam me aconselhar. Fui o primeiro dos bairros populares do Centro da cidade a entrar na Manchester Grammar School. É como no Brasil, a maioria das pessoas que entram para a Manchester Grammar School vem da educação privada. São treinadas para passar nos exames. Todo ano há I0.000 concorrentes de uma área que se estende em um raio de 40-50 milhas do Centro da cidade. Você só pode fazer o exame se seu diretor o recomendar. Assim, você tem I0.000 escolhidos de professores vindos de toda a região. Eles reduzem de I0.000 para 2.000 na primeira etapa, e você faz um segundo exame, e eles tiram 200 de 2.000. E é isso. Eu saí na capa do jornal local por ter ganho uma vaga. Eu não tinha precedente algum. Eu não sabia quanto trabalho tinha que fazer para chegar onde queria. Então eu trabalhei em excesso. Com I 8 anos, eu já tinha lido quase tudo o que existe em latim e grego, só não sabia quando parar. Eu havia sacrificado tudo para fazer isso. Mas os exames eram avaliados anonimamente. Em outras palavras, você preenche o exame e ele vai não sei aonde. Alguém que você nunca conheceu lê o seu exame. Eu sabia que havia trabalhado o suficiente para passar nos exames, mas e se o cara que está corrigindo meu trabalho o faz mal? Eu tinha que influenciá-lo de alguma maneira. A primeira coisa que fiz foi ler sobre caligrafia. Inclinada para a frente é extrovertido e introvertido inclinada para trás, e grandes voltas é psicótico - todo esse tipo de coisa [Risos]. 
Eu então desenvolvi um estilo de caligrafia que é regular, mas característico e facilmente legível. Assim pelo menos o cara pode dizer, "obrigado, Deus, uma escrita que eu consigo ler!" Mas eu sou um romancista fracassado, eu imaginei um cara nos seus 50 anos que está no seu quarto whisky, é uma hora da manhã, e ele tem 50 trabalhos para examinar. Que acontece se ele diz, "ah foda-se, eu vou dar um B e sigo em frente”. Como eu vou conseguir sua atenção? Eu decidi colocar uma piada no primeiro parágrafo. Ou ele gosta da piada, nesse caso eu estaria à frente, ou não gosta da piada, mas pelo menos está lendo. Essa é a experiência central que me fez um antropólogo. Eu não consigo suportar depender de uma sociedade impessoal. Eu tenho que fazer uma conexão pessoal que me dê mais chances. Na ausência de qualquer contato real, vou criar uma ficção que preencha essa distância. Todo esse negócio sobre a economia informal e caras e coroas, pessoal e impessoal, é reduzível a esta única questão: como diabos eu, o pequeno Keithy de Old Trafford, vou lidar com tudo isso que está lá fora? Minha vida depende disso. Eu lembro de um filme chamado Billy Elliot, que é sobre um garoto da mineração que era dançarino. ${ }^{9}$ Tem um momento em que ele é entrevistado para a escola nacional de ballet e depois ele tem que esperar por uma resposta em casa. Um envelope marrom chega por debaixo da porta com a resposta: ele está dentro ou está fora? Ele não quer abri-lo na frente da família. Prefere não saber do que saber o pior. Eu entendo esse sentimento tão bem. Minha vida depende do que está dentro desse envelope marrom. Eu definitivamente quero ter as coisas mais do meu lado do que elas estavam quando comecei, mas eu quero fazer isso de uma maneira que também possa ajudar aos outros, para preencher a enorme distância entre a imensidão das forças que nos esmagam e nossa própria personalidade com seus desejos. Como podemos trazê-los para perto um do outro, fazer algum tipo de conexão significativa? O intercâmbio com o examinador imaginário quando era adolescente foi a origem disso.

F.R. Esse é o espírito da Open Anthropology Cooperative, não é? Preencher a distância? Construir pontes?

K.H. Sim, a Open Anthropology Cooperative é muito interessante. Era um grupo de pessoas, a maioria delas estudantes de graduação, que se encontraram no Twitter, e começamos a trocar ideias sobre como seria bom ter uma associação online. Esse grupo do Twitter se mudou para o meu website para criar um fórum de discussão, e então alguém disse, você já tentou Ning? Então eu fui, procurei Ning e comecei. [Ela tem 22.000 membros em 2018] Ninguém me delegou essa função, eu não estava trabalhando para ninguém, eu nem mesmo sabia que, depois de ter colocado meu endereço de e-mail, eu seria para sempre identificado como o fundador dessa coisa. Mas é daí de onde ela vem. Eu estive envolvido em tentar auto-organizar comunicações desde os anos I990. Eu formei em 
Cambridge algo chamado de Associação Antropológica Amadora [Amateur Anthropological Association] ou a pequena Triple A (você sabe, não o grande Triple A $[\mathrm{AAA}]),{ }^{\mathrm{I}}$ e isso se tornou uma lista de endereços depois de um tempo. Há um potencial tremendo nesses sites de redes sociais. Tendo estado nisso por 20 anos, estou convencido de que as habilidades necessárias para fazer o melhor uso desses meios são cada vez mais sociais do que técnicas. Quando eu comecei, dependia dos nerds porque eu não entendia nada disso. Cada vez está se tornando mais fácil se conectar e usar. Neste momento, as reais habilidades empreendedoras são sociais. Sei que eu as tenho, mas a OAC também coincidiu com minha aposentadoria. Talvez estivesse criando minha própria universidade no meu laptop para compensar o fato de que eu não estava mais trabalhando em uma universidade. As três palavras do nome são significativas. Uma é "open access", essa é bastante fácil. A segunda, "anthropology", nós temos que repensar, deixamos muitas antropologias florescerem. A mais difícil das três é "cooperative", porque o verdadeiro potencial dessa aposta é a colaboração. Isso é difícil de alcançar. É difícil conseguir que as pessoas sejam ativas, mas ser ativos juntos é mais difícil ainda. Começamos uma série de publicações, intitulada Open Anthropology Cooperative (OAC) Press (<http://openanthcoop.net/press/>) e publicamos trabalhos em andamento, geralmente para seminários online. Fazemos um seminário durante duas semanas e produzimos um artigo previamente, a discussão é arquivada e é acessível permanentemente. Agora temos todo esse material em e-books. Fizemos uma série chamada Interventions, que é de ensaios reciclados ou novos de antigos nomes, incluindo dois trabalhos de Sidney Mintz e outro de Jean La Fontaine. Dependemos muito dos estudantes de pós-graduação, e os estudantes de pós-graduação têm dois problemas: querem ser antropólogos profissionais, o que significa que são bastante conservadores, e pensam que o que fazem online é uma distração do que deveriam estar fazendo, sua tese. Então é difícil conseguir que as pessoas se comprometam como eu o faço. A segunda língua dos participantes é português, de Portugal e do Brasil.

F.N. Todas essas novas formas de diálogo e plataformas de rede parecem refletir o que está acontecendo com a antropologia no mundo hoje. Qual é a sua percepção? O que está acontecendo na disciplina agora, nos centros tradicionais como a França, Inglaterra e América e nos "emergentes", como o Brasil e muitos outros?

K.H. Um dos problemas com a OAC é que quase metade dos visitantes é dos EUA e da Inglaterra. Nossos membros são incrivelmente globais. É realmente emocionante, eles vêm de todas as partes, Mongólia, de qualquer lugar que você possa imaginar. É simplesmente incrível. Então de alguma forma as barreiras ao acesso 
para pessoas de fora não são proibitivas. Mas as pessoas que demonstraram o primeiro e o maior entusiasmo foram os lusófonos. Os franceses não são realmente muito entusiasmados com isso, eles também não participam da Easa. A França acabou sendo o terceiro maior visitante, mas isso principalmente por minha causa! Ela conta todas as minhas visitas ao site como França. ${ }^{\text {II }}$ [Risos.] Eu sempre senti que a antropologia profissional deveria se abrir para a troca com pessoas interessadas vindas de fora da disciplina. Eu realmente acredito que a antropologia é mais conservadora e até redundante nos antigos centros imperiais, na França, Inglaterra e América. Tenho enorme satisfação com as variações regionais e nacionais na antropologia. Sempre cito a Escandinávia - Finlândia, Suécia, Noruega e Dinamarca. Duas coisas. A primeira é que o modelo social-democrata não foi eliminado lá, e a segunda, os antropólogos lá têm um senso de responsabilidade pública por causa desse modelo social-democrata. A Noruega publicou uma lista dos dez melhores intelectuais públicos e três deles eram antropólogos. O número um era Thomas Hylland Eriksen, e o número cinco, antes de ela falecer, era Marianne Gullestad, o número sete era Unni Wikan, a mulher de Frederik Barth. Em Estocolmo, Ulf Hannerz foi uma estrela quando tinha I4 anos, ao receber um prêmio de TV por identificar um peixe exótico. Mas ele foi também um herói nacional pelo seu PhD quando apresentou Soulside (Hannerz, I969). Um examinador era Michael Banton, um sociólogo inglês, o outro era um antropólogo sueco, e o sueco rejeitou a tese, argumentando não ser boa o suficiente para um $\mathrm{PhD}$. Os estudantes manifestaram-se nas ruas em favor de Ulf, então ele foi para a televisão mais uma vez. Você sabe a história sobre o peixe? Isso foi nos anos I950, quando todo mundo via TV no domingo à noite; a pergunta valia 64,000 dólares, e ele chegou na rodada final. A Suécia inteira estava assistindo a esse garoto de 14 anos, e eles lhe dão uma série bem complicada de questões. Ele responde certo na primeira, certo na segunda, certo na terceira, certo na quarta, e então eles dão uma lista de cinco coisas, e ele identifica as cinco coisas, e o apresentador diz: "ah, sinto muito, você cometeu um erro". E esse garoto de I4 anos, Ulf, meu amigo, diz: "Eu acho que você vai descobrir que estou certo". Então eles, em seguida, apanharam livros e descobriram que havia dois nomes para esse peixe, ele deu um deles, o programa o outro. Assim, primeiro a Suécia inteira ficou "ah, o garoto quase conseguiu, mas falhou!" e depois, "mas o garoto ganhou!!”. Então ele virou um herói nacional, literalmente. E depois, em I968, houve estudantes marchando nas ruas para defender seu PhD. Sempre achei que tenho um mercado na Escandinávia, o que é ótimo, porque eu acho que eles gostam de discurso direto, há algo na minha personalidade, minha perspectiva política, meu estilo de comunicação, que eles gostam. Quanto ao Brasil, uma questão importante para identificar as possibilidades para a antropologia em determinados países é olhar para a divisão acadêmica do trabalho nas ciências sociais. Então, por exemplo, na Inglaterra, a sociologia é muito católica e universal, a ciência política é muito restrita, sobre governo e assim por diante. Na América, a ciência política é católica e a sociologia é muito restrita e 
formal. Eu não sei isso tão bem quanto vocês, mas meu entendimento do Brasil é que a sociologia e a ciência política ficaram presas a um estilo bastante rígido e antiquado, marxista ou qualquer outra coisa do tipo, e assim isso abriu para os antropólogos a possibilidade de se voltar para a sociedade urbana contemporânea, assim como manter seu reduto amazônico. Assim, as possibilidades para a antropologia aqui são enormes. Obviamente a antropologia social floresceu na Inglaterra antes da guerra porque não havia realmente uma sociologia viável. A classe dominante britânica decidiu que eles não queriam uma sociologia da GrãBretanha, mas uma sociologia do império colonial, o que significou que os antropólogos sociais tiveram um escopo muito mais amplo para dirigir-se ao público do que teriam se eles fossem competir com uma sociologia bem estabelecida. Esse tipo de coisa importa, quais circunstâncias permitem antropólogos assumir uma presença mais expansiva e pública? O ponto principal, entretanto, é que a antropologia não é mais uma coisa. É muitas coisas. Não é sempre progressista. Tem países enormes, como a Índia e a Nigéria, onde muitos antropólogos estão focalizando os chamados estudos tribais. Tenho certeza de que isso envolve um bom trabalho, original, mas as questões mais amplas da sociedade contemporânea são negligenciadas. Alguns dos antigos assentamentos do Império britânico, como África do Sul, Nova Zelândia, Austrália e Canadá, têm antropologias bem vivas. Em parte, eu refiz minha vida na África do Sul. Sempre tem sido um lugar muito importante para a antropologia, e agora estou organizando pesquisas na maior universidade de lá, que é Pretoria, um antigo bastião dos africânderes, onde o bantustão e as políticas de apartheid foram formadas. As universidades liberais como a da Cidade do Cabo e a Witwatersrand University, de Johanesburgo, pensavam estar no lado certo na luta antiapartheid enquanto consideravam que os africânderes estavam perseguindo uma antropologia antiquada, racista e alemã. $\mathrm{Na}$ verdade, os antropólogos ingleses da África do Sul tendiam a argumentar naquela época que os africanos eram rurais ou tribais e as cidades eram brancas, enquanto os antropólogos africânderes, inspirados em Thrasher e na sociologia americana da dinâmica das ruas, estavam dizendo que essas pessoas eram iguais a eles e que havia muitos mais deles. Estavam propondo enviá-los de volta ao campo, com base em uma interpretação muito moderna de que os africanos não eram substancialmente diferentes de nós. A África do Sul tem sido sempre uma fonte muito importante de antropólogos - pessoas como Max Gluckman, Radcliffe-Brown, Fortes, Schapera e Hilda Kuper.

F.R. E agora você está trabalhando não só com sul-africanos, mas com pessoas vindas de outras partes do mundo.

K.H. Sim, para o livro The human economy, eu peguei um discurso que era exclusivamente francófono e latino-americano e adicionei autores escandinavos, britânicos e americanos, traduzindo uma grande quantidade desse material para o 
inglês. Mas quando foi concluído, ficou evidente que nele não havia africanos e asiáticos. Portanto, esse é um processo contínuo, em que cada passo empurra o barco um pouco mais longe. A próxima etapa será trazer mais contribuições africanas e asiáticas, em diálogo com a América Latina. Penso em mim como remontando um homem Ibsa, que é um acrônimo para a associação de Índia, Brasil e África do Sul. Faz um tempo que venho acumulando conexões no Brasil e na Índia, e considero esses três países os lugares mais promissores do planeta. Sempre tenho gostado da Índia, também acho a África do Sul um lugar esperançoso e fico triste pela reputação global que tem por causa do crime e da violência. Há conflitos, mas todas as classes e raças têm um lugar na nova África do Sul. Os brancos estão melhor do que poderiam esperar, talvez muito bem; os indianos estão muito presente nas profissões e nos serviços públicos; os negros sul-africanos são cidadãos plenos na economia africana mais forte; e os africanos que vieram de fora sabem que eles estão com melhores chances. Há, é verdade, conflitos importantes entre os dois tipos de África, os brancos estão começando a dar por garantida a sua superioridade e os seus privilégios, e o governo da ANC possui muitas falhas. Mas esse país tem apenas roo anos de idade. A África do Sul foi formada em I9Io, tornou-se uma república racista em I96I, e teve um governo de maioria africana em I 994. Pouco tempo, no final das contas. O país é jovem, é bonito, e as pessoas são calorosas. Brancos, pardos, negros, eles são calorosos. Não há comparação perto da França ou da Inglaterra. As pessoas do Norte são deprimidas. Vivendo em Paris, tenho que ir para a África do Sul para escapar da depressão. Lembro-me de conversar com uma mulher francesa que me perguntou, "Sobre o que é o seu livro?" "Eu estou escrevendo um livro sobre o futuro urbano africano, onde haverá importantes melhorias econômicas." Ela estava olhando feio para mim, então eu finalmente disse: "Bem, claro que grande parte da África é uma bagunça”. Ela disse: "Sim, é uma bagunça". Então eu perguntei, "Você já esteve lá?” Ela disse: “Não, não, eu nunca estive lá." Para ela e para muitos a ela semelhantes, os negros pobres e sem esperança são a prova permanente de que ser francês é melhor. Na Inglaterra também. Tenho pensado em um livro que vai ser difícil realizar, mas cuja mensagem é que o jogo acabou. ${ }^{\text {I2 }}$ O Ocidente esteve obtendo rendimentos vindos do resto do mundo durante 500 anos, e os outros não estão mais dispostos a pagar. Os europeus nem podem reproduzir-se, mas quando eles trazem essas pessoas da África, do Oriente Médio e da Europa Oriental para trabalhar a fim de que possam se aposentar, eles os odeiam por isso. O livro é para os africanos em primeiro lugar, mas também é para os europeus, dizendo que isso é para vocês, o jogo acabou. [Risos.]

F.N. Obrigado pela entrevista. O jogo acabou. 
Federico Neiburg é professor do Programa de Pós-Graduação em Antropologia Social, Museu Nacional, UFRJ. Pesquisador do CNPq.

Coordena o Núcleo de Pesquisas em Cultura e Economia (www. cultura-economia.org). Desenvolve pesquisas na área de antropologia econômica sobre os temas moedas, mercados, dinâmicas familiares e políticas, mobilidade e circulação de pessoas, objetos e dinheiro. Publicou os livros: A cultural history of money. The Age of Empire (I 820I920) (com Dood, N.) (20I8); Norbert Elias. Escritos e Ensaios I - Estado, processo, opinião pública (com Waizbort, L.) (2006); Empires, nations, and natives: anthropology and state-making (com L'estoile, B.; Sigaud, L.) (2005) e Los intelectuales y la invención del peronismo. Estudios de antropología social y cultural (I998).

Fernando Rabossi é professor do Departamento de Antropologia Cultural e do Programa de Pós-Graduação em Sociologia e Antropologia da UFRJ. Sua pesquisa focaliza a relação entre regras e práticas econômicas. É autor do livro En las calles de Ciudad del Este: una etnografía del comercio de frontera (2008) e de diversos artigos sobre economias e políticas informais, processos de formalização, mercados, fronteiras, circulação e etnografia. 


\section{NOTAS}

I De acordo com o autor, o capitalismo de Estado (State capitalism) foi a configuração predominante durante a Guerra Fria na qual o Estado, e não o mercado, teve papel preponderante na estruturação do capitalismo, papel que é resultado da convergência da burocracia estatal e do capitalismo industrial. Nessa formulação, Hart recupera as discussões de C.L.R. James (James, Dunayevskaya \& Lee, I950), o historiador e intelectual trinitário que teve influência decisiva no seu pensamento. C.L.R. James (1963) é o autor de Black jacobins, de I938, hoje um clássico sobre a independência haitiana. [N.T.]

2 Os textos estão disponíveis em: <http://thememorybank. co.uk/2009/05/25/prickly-pear-pamphlets/>. Acesso em 22 out. 2018. A partir de 200I, passaram a ser editados por outros sites, como o Prickly Pradigm, disponível em: $<$ http://prickly-paradigm.com/>. Acesso em 22 out. 2018. [N.T.]

3 Seguidor de Jeremy Bentham, filósofo e economista considerado o pai do utilitarismo. [N.T.]

4 O livro The developmental cycle in domestic groups foi editado por Jack Goody (I958). Ele explorava as ideias de Meyer Fortes a respeito do ciclo de mudanças dos grupos domésticos e as consequências para a dinâmica social destacada em seu artigo Time e Social Structure: an Ashanti case study (Fortes, I949). [N.T.]

5 Na época, a categoria étnica frafra incluía quatro grupos, sendo um deles os Tallensi. [N.T.]

6 Tenure é o direito de estabilidade no cargo como professor universitário. [N.T.]

7 "The two sides of money" foi apresentado por Keith Hart como uma palestra em memória a Malinowski, na London School of Economics, em I3 de março de i986. [N.T.]

8 O colóquio Mauss vivant, de 2009, foi organizado por Alan Caille e Keith Hart, reunindo um conjunto significativo de participantes que abordaram a relevância contemporânea dos escritos de Marcell Mauss. Sobre o legado de Mauss, ver o texto de Keith Hart e Wendy James (20I4). [N.T.] 
9 Billy Eliot, dirigido por Stephen Daldry, 2000. [N.T.]

Io Se refere à sigla da American Anthropological Association (AAA). [N.T.]

I I Keith Hart vive com sua família em Paris desde I997.

I2 Africa 2I00: A history of the future (ainda em preparação). I 2 palestras (MP3s) sobre "África na história mundial", disponível em: <https://soundcloud.com/soasradio/sets/ africa-in-world-history-lectures-by-keith-hart $\geq$. Acesso em 22 out. 2018.

\section{REFERÊNCIAS BIBLIOGRÁFICAS}

Fortes, Meyer. (1949). Time and social structure: an Ashanti case study. In: Fortes, Meyer (ed.) Social structure: studies presented to A.R. Radcliffe-Brown. Oxford: Clarendon, p. 54-84. Geertz, Clifford. (1963). Peddlers and princess: social change and economic modernization in two Indonesian towns. Chicago/ London: The University of Chicago Press.

Goody, Jack. (1958). The developmental cycle in domestic groups. Cambridge: Cambridge University Press.

Hannerz, Ulf. (I969). Soulside: inquiries into ghetto culture and community. New York: Columbia University Press.

Hart, Keith. (20I7). Greybacks. In: Maurer, Bill \& Swartz, Lana (eds). Paid: tales of dongles, checks, and other money stuff. Cambridge, MA: The MIT Press, p. 2II-222.

Hart, Keith. (2008) [2005]. Africa on my mind. Disponível em: <http://thememorybank.co.uk/2008/or/I4/africa-onmy-mind/>. Acesso em 22 out. 2018.

Hart, Keith. (2005). The hit man's dilemma: or business, personal and impersonal. Chicago: University of Chicago Press/ Prickly Paradigm Press.

Hart, Keith. (2000). The memory bank: money in an unequal world. London: Profile Books. (Republicado em 200I como Money in an unequal world. New York/London: Texere).

Hart, Keith. (1992). Market and State after the Cold War: the informal economy reconsidered. In: Dilley, Roy (ed.). Contesting markets: analyses of ideology, discourse and practice. Edinburg: Edinburg University Press, p. 214-227.

Hart, Keith. (I986). Heads or tails? Two sides of the coin. 
Man, 2I/4, p. 637-656.

Hart, Keith. (I982). The political economy of West African agriculture. Cambridge: Cambridge University Press.

Hart, Keith. (1978). The economic basis of Tallensi social history in the early twentieth century. In: Dalton, G. (ed.). Research in economic anthropology, v.I. Greenwich, CT: JAI Press, p. I85-216.

Hart, Keith. (I973). Informal income opportunities and urban employment in Ghana. Journal of Modern African Studies, II/3, p. 6I-89.

Hart, Keith \& James, Wendy. (20I4). Marcel Mauss: a living inspiration. Journal of Classical Sociology, I4/I, p. 3-Io.

Hart, Keith; Laville, Jean-Louis \& Cattani, Antonio David (eds). (20Io). The human economy: a citizen's guide. Cambridge: Polity Press.

James, C.L.R. (1963) [1938]. The black jacobins: Toussaint L'Ouverture and the San Domingo Revolution. New York: Vintage.

James, C.L.R.; Dunayevskaya, R. \& Lee, G. (I950). State capitalism and world revolution. Chicago: Charles H. Kerr.

Lomnitz, Larissa Adler de. (1993) [1975]. Cómo sobreviven los marginados. Mexico: Siglo XXI Editores.

McGee, Terence. (I97I). The urbanization process in the Third World. London: G. Bell and Sons, Ltd.

Parry, Jonathan. (I986). The gift, the Indian gift and the "Indian gift". Man, 2I/3, p. 453-473.

Parry, Jonathan \& Bloch, Maurice (eds). (I989). Money and the morality of exchange. Cambridge: Cambridge University Press.

Salhins, Marshall. (I993). Waiting for Foucault. Cambridge: Prickly Paradigm Press.

Schumpeter, Joseph A. (I954). History of economic analysis. London: Allen \& Unwin.

Strathern, Marilyn. (1995). The relation: issues in complexity and scale. Cambridge: Prickly Paradigm Press. 


\section{ANTROPOLOGIA E ECONOMIA. TENTANDO FAZER UMA CONEXÃO SIGNIFICATIVA: ENTREVISTA DE KEITH HART \\ Resumo}

Keith Hart narra sua trajetória intelectual desde seus primeiros cursos em letras clássicas até sua conversão à antropologia. Acentua a mudança de perspectiva teórico-conceitual provocada por sua geração e os impactos dessas novas pesquisas realizadas na África urbana, o que, por sua vez, deu outra feição à antropologia econômica que, ao se afastar dos modelos clássicos, avança para uma antropologia dos mercados, do trabalho informal, do dinheiro e das novas relações sociais instituídas pelas migrações que formam a nova faceta do mundo urbano contemporâneo. A entrevista é, também, uma fonte importante para a história da antropologia anglo-saxã ao tratar de seus bastidores, da relação entre Keith Hart e Jack Goody e das tensões e distanciamentos com a geração de Meyer Fortes e de Evans-Pritchard. Também revela os vaivéns dos debates sobre desenvolvimento, a constituição dos novos espaços pós-coloniais e as experimentações contemporâneas na economia e na antropologia.

\section{ANTHROPOLOGY AND ECONOMY TRYING TO MAKE A MEANINGFUL CONNECTION: INTERVIEW WITH KEITH HART} studies carried out in urban Africa. These, in turn, added an other dimension to economic anthropology, which, moving away from classical models, advanced towards an anthropology of markets, informal work, money and the new social relations instituted by migrations that form the new face of the contemporary urban world. The interview is also an important source of behind-the-scenes information on the history of Anglophone anthropology, including the relationship between Keith Hart and Jack Goody, and the tensions and distances in relation to the generation of Meyer Fortes and EvansPritchard. It also reveals the ups and downs of development debates, the constitution of new postcolonial polities, and contemporary experiments in economics and anthropology.
Palavras-chave

Antropologia; informalidade; dinheiro; África; desenvolvimento.
Keywords Anthropology; informality; money; Africa; development. 